\title{
Biology and Molecular Characterization of Cucurbit leaf crumple virus, an Emergent Cucurbit-Infecting Begomovirus in the Imperial Valley of California
}

\author{
C. Hagen and M. R. Rojas, Department of Plant Pathology, M. R. Sudarshana, Western Institute for Food Safety \\ and Security, and B. Xoconostle-Cazares, Depto. Biotecnología, CINVESTAV Mexico. Av. IPN 2508 Zacatenco \\ 07360 Mexico D.F.; E. T. Natwick, University of California Cooperative Extension, UC Desert Research \& Exten- \\ sion Center (UCCE), Holtville 92250; T. A. Turini, UCCE, Cooperative Extension Fresno County, Fresno 93702; \\ and R. L. Gilbertson, Department of Plant Pathology, University of California, Davis
}

\begin{abstract}
Hagen, C., Rojas, M. R., Sudarshana, M. R., Xoconostle-Cazares, B., Natwick, E. T., Turini, T. A., and Gilbertson, R. L. 2008. Biology and molecular characterization of Cucurbit leaf crumple virus, an emergent cucurbit-infecting begomovirus in the Imperial Valley of California. Plant Dis. 92:781-793.

Cucurbit leaf crumple virus (CuLCrV) is an emergent and potentially economically important bipartite begomovirus first identified in volunteer watermelon plants in the Imperial Valley of southern California in 1998. Field surveys indicated that $\mathrm{CuLCrV}$ has become established in the Imperial Valley; and field plot studies revealed that $\mathrm{CuLCrV}$ primarily infects cucurbits, including cantaloupe, squash, and watermelon. Full-length DNA-A and DNA-B clones of an Imperial Valley isolate of $\mathrm{CuLCrV}$ were obtained by polymerase chain reaction (PCR) with overlapping primers. These clones were infectious in various cucurbits and common bean (cv. Topcrop); symptoms included stunted growth and leaf crumple, curl, and chlorosis. CuLCrV was not saptransmissible, and immunolocalization and DNA in situ hybridization studies revealed that is phloem-limited. A CuLCrV agroinoculation system was generated, and host range studies revealed differential susceptibility in cucurbits, with squash, watermelon, cantaloupe, and honeydew melon being most to least susceptible, respectively. Germplasm screening studies identified a number of resistant cantaloupe and honeydew melon cultivars. The genome organization of this $\mathrm{CuLCrV}$ isolate (CuLCrV-CA) is similar to other bipartite begomoviruses, and phylogenetic analysis placed $\mathrm{CuLCrV}$ in the Squash leaf curl virus (SLCV) cluster of New World bipartite begomoviruses. A CuLCrV-specific PCR test was developed which allows for differentiation from other begomoviruses, including SLCV.
\end{abstract}

Outbreaks of the B biotype of the sweet potato whitefly (Bemisia tabaci Genn.) have facilitated the worldwide emergence of whitefly-transmitted geminiviruses (genus Begomovirus) as constraints on vegetable and fruit crops $(4,26,29)$. Cucurbits are a preferred host of $B$. tabaci, and begomovirus-induced diseases have become increasingly important in melon, squash, and watermelon. The first cucurbit-infecting begomovirus described was Squash leaf curl virus (SLCV), which was associated with leaf curl and stunted growth of squash in the Imperial Valley of California in the early 1980s $(7,10)$. Subsequently, SLCV was reported infecting watermelon in Arizona (19) and Mexico (37). Molecular studies revealed two genetically distinct begomoviruses associated with squash leaf curl disease, and these were named the extended (SLCV-E) and restricted (SLCV-R) host range strains

Corresponding author: R. L. Gilbertson

E-mail: rlgilbertson@ucdavis.edu

Accepted for publication 29 November 2007.

doi:10.1094/PDIS-92-5-0781

(C) 2008 The American Phytopathological Society
(22). The level of sequence identity between SLCV-E and SLCV-R is lower than the currently accepted limit for strains (90\%); therefore, SLCV-E was renamed SLCV and SLCV-R was renamed Squash mild leaf curl virus (SMLCV). It is believed that SMLCV is predominant in the Imperial Valley, because watermelon has not been affected by squash leaf curl disease. Additional Begomovirus spp. have been described infecting watermelon in the Sudan, squash in Costa Rica, and melon in Guatemala $(16,20,21,41)$.

Thus, in fall 1998, when watermelon volunteers were observed with chlorosis, leaf crumpling, and curl symptoms on the outskirts of the Imperial Valley, it was presumed to be an outbreak of SLCV. Polymerase chain reaction (PCR) analyses confirmed a Begomovirus sp. infection in these plants; however, sequence analysis of the PCR-amplified fragments suggested infection with an uncharacterized Begomovirus sp. Subsequent analyses confirmed the presence of a new Begomovirus sp., and the name Cucurbit leaf crumple virus $(\mathrm{CuLCrV})$ was proposed (15). Sequence comparisons and phylogenetic analyses revealed that $\mathrm{CuLCrV}$ was most closely related to $\operatorname{SLCV}(5,15)$, and this was further supported by the capacity of a
$\mathrm{CuLCrV}$ isolate from Arizona (referred to as Cucurbit leaf curl virus) to form infectious pseudorecombinants with SLCV (5).

The Imperial Valley of California has spring and fall cantaloupe and honeydew melon growing seasons, with a total production of approximately 8,000 acres in 2005 (3). Spring planting begins in late December with harvests in May through early July, whereas fall planting begins in late July to early August with harvests in mid-October through early December. Thus, the emergence of a new cucurbitinfecting Begomovirus sp. presented a potential economic threat to melon production in the Imperial Valley. Indeed, during the 1999 growing season, symptoms of yellowing and leaf crumple or curl appeared in spring- and fall-grown cantaloupe plants, indicating that the virus had overwintered and spread into commercial melon production.

A study was initiated to understand the biology of this new Begomovirus sp. and to assess the potential threat that this virus poses for melon production in the Imperial Valley. Field surveys for $\mathrm{CuLCrV}$ incidence and severity in commercial fields were conducted from 1999 to 2003, field trials were conducted to assess the host range of $\mathrm{CuLCrV}$, a CuLCrV-specific PCR detection method was developed, and infectious DNA-A and DNA-B clones of an Imperial Valley isolate were generated. An agroinoculation system was developed and used to screen cucurbits for resistance to $\mathrm{CuLCrV}$, and sequence and phylogenetic analyses were performed to gain insight into the origin of this new Begomovirus sp. This information has provided growers an idea of the potential threat posed by this virus to commercial cucurbit production, as well as potential management strategies.

\section{MATERIALS AND METHODS}

Surveys for the incidence of $\mathrm{CuLCrV}$ in the Imperial Valley. Surveys of springand fall-planted cucurbits in the Imperial and Coachella Valleys of California were conducted from 1999 to 2003. Commercial cucurbit (cantaloupe, honeydew, and squash) fields and experimental plots at the Desert Research and Extension Center (DREC) in Holtville, CA, were surveyed for the presence of viral symptoms (stunted and distorted growth and leaf curl, 
crumple, and mosaic or mottle) and whiteflies. In each field, a minimum of 50 plants from two or more locations within the field was examined visually for virus symptoms, and samples were collected from plants showing representative symptoms. The presence and relative abundance (high, medium, or low) of whiteflies was determined in each field by examining the underside of at least 10 leaves.

In 1999 and 2000, field plots were established at the DREC in which a range of crop plants were planted in August of each year to assess the host range of CuLCrV. The following cucurbit species were planted: Cucurbita pepo: acorn squash, birdhouse gourd, yellow crookneck squash, and zucchini squash; Cucumis melo: ananas melon, cantaloupe, casaba melon, charentais melon, galia melon, golden crenshaw melon, and honeydew melon; Cucurbita palmate; C. maxima: blue Hubbard squash, turks turban gourd, and pumpkin; and $C$. moschata: butternut squash. Noncucurbits included common bean (Phaseolus vulgaris), cotton (Gossypium hirsutum), pepper (Capsicum annuum), soybean (Glycine max), and tomato (Solanum lycopersicum). Samples were collected from symptomatic and nonsymptomatic plants.

Samples collected during surveys or from plants in the host range plots were sent to or brought back to University of California, Davis. Leaf discs were squashed onto nylon membranes as previously described (13), or DNA was isolated using the Dellaporta method $(9,30)$. Squash blots were hybridized with a general probe for whitefly-transmitted begomoviruses (13), and aliquots of DNA extracts were used in PCR with degenerate begomovirus primers (30) or CuLCrV- and SLCV-specific PCR primer pairs (see below).

Generation of full-length $\mathrm{CuLCrV}$ DNA-A and DNA-B clones. Putative fulllength CuLCrV DNA-A and DNA-B clones were generated using PCR and the overlapping primer method (28). Overlapping primers were generated from sequences of PCR-amplified DNA-A and DNA-B fragments (15) and used to direct the amplification of putative full-length DNA-A and DNA-B components. The following overlapping primer pairs with the indicated restriction sites were designed for CuLCrV DNA-A: CuLCrVAEcoRI-V (5'-GAATTCTCTGCCTGA AACCGC-3') and CuLCrVA-EcoRI-C (5'-GAATTCCGCTTTTATCTGGGA-3'); and for DNA-B: CuLCrVB-ApaI-V (5'GGGCCCATTAACAGGCCCAGGCCC$\left.3^{\prime}\right)$ and CuLCrVB-ApaI-C (5'-GGGCCC TGAGATGGGCCTGTGAGC-3'). PCR was performed using $P f u$ proofreading thermostable DNA polymerase (Stratagene, La Jolla, CA) and a DNA extract prepared from watermelon leaves with typical $\mathrm{CuLCrV}$ symptoms collected in the Imperial Valley in 2000. PCR-amplified
DNA products of the expected size (approximately $2.6 \mathrm{~kb}$ ) were cloned into plasmid pZeroBlunt (Invitrogen, Carlsbad, CA) according to the manufacturer's protocol. Recombinant plasmids with putative full-length DNA-A and DNA-B clones were identified by restriction enzyme digestion analysis and designated pCuLCrVA and pCuLCrVB, respectively.

Production of multimeric CuLCrV DNA-A and DNA-B clones. A multimeric CuLCrV DNA-A clone (pCuLCrVA1.5) was constructed by separately digesting pCuLCrVA with BglII and EcoRI and $E c o$ RI and $A p a \mathrm{I}$, respectively, and gel purifying the resulting $1.9-$ and $2.2-\mathrm{kb}$ fragments. These fragments were ligated together and the resulting 4.1-kb fragment (representing approximately 1.6 mer with two common region [CR] sequences) was cloned into pBluescript II KS- (Stratagene) digested with $B g l I I$ and ApaI, to generate pCuLCrVA1.5. A multimeric CuLCrV DNA-B clone (pCuLCrVB1.5) was constructed by separately digesting pCuLCrV-B with $B g l \mathrm{II}$ and $A p a \mathrm{I}, A p a \mathrm{I}$ and $N s i$ I, and $N s i$ I and EcoRI, respectively, and gel purifying the resulting 0.6-, 0.9-, and $1.7-\mathrm{kb}$ fragments. These fragments were ligated together, and the resulting 3.2-kb fragment (representing approximately 1.2 mer with two $\mathrm{CR}$ sequences) was cloned into pBluescript II KS- digested with BamHI and EcoRI to generate pCuLCrVB1.5.

Particle bombardment inoculation. Infectivity of putative full-length $\mathrm{CuLCrV}$ DNA-A and DNA-B monomers released from pCuLCrVA and pCuLCrVB was determined by particle bombardment of cucurbit (one- to two-true leaf stage) or Nicotiana benthamiana (five- to seven-leaf stage) seedlings or hypocotyls of 48-h-old common bean seedlings (cvs. Topcrop and Othello) as previously described $(11,36)$. Bombarded bean seedlings were transplanted into soil and plants were maintained in a controlled-environment growth chamber (light intensity, $300 \mu$ Einsteins; temperature, 30 and $25^{\circ} \mathrm{C}$ day and night, respectively; 16-h day length; and relative humidity of approximately $60 \%$ ) or a greenhouse maintained between 25 and $28^{\circ} \mathrm{C}$. Symptoms were assessed 10 and 21 days post bombardment (dpb) and, in some cases, infections were confirmed by PCR analysis with degenerate or CuLCrVspecific primers.

Sap transmission, immunolocalization, and in situ DNA hybridization. Sap transmission was conducted as described by Gilbertson et al. (13). Sap was prepared with ice-cold $0.1 \mathrm{M}$ potassium phosphate buffer and young symptomatic leaf tissue collected from watermelon seedlings infected with $\mathrm{CuLCrV}$ via particle bombardment inoculation with infectious DNA-A and DNA-B clones. Sap was rubbed onto celite-coated leaves of small sugar pumpkin (cotyledon stage), common bean (cv. Topcrop, primary leaf stage), and $N$. benthamiana (four- to six-true-leaf stage) plants. The positive control was sap similarly prepared from leaves of $N$. benthamiana plants infected with the saptransmissible bipartite Begomovirus sp., Bean dwarf mosaic virus (BDMV).

Immunolocalization experiments were conducted with $\mathrm{CuLCrV}$-infected zucchini (cv. Elite) approximately 4 weeks post inoculation and equivalent uninfected plants. A begomovirus capsid protein (CP) antibody was used for immunolocalization (40). Tissue preparations, sectioning, and immunolocalization was performed as described by Rojas et al. (32). For localization of CuLCrV DNA, in situ DNA hybridization analysis was used. Here, tissue was sampled from CuLCrV-infected zucchini (approximately 4 weeks post inoculation) and prepared as described by RuizMedrano et al. (33). Briefly, a 400-bp DNA fragment of the CuLCrV CP open reading frame (ORF) was amplified by PCR and cloned into the TOPO II dual promoter vector (Invitrogen). The vector was linearized with XhoI or HindIII and used to transcribe digoxigenin (DIG)labeled sense or antisense RNA, respectively, using the MAXIscript kit (Ambion, Austin, TX). In situ hybridization was performed as described by Ruiz-Medrano et al. (33). DIG-labeled RNA was detected with the anti-DIG antibody conjugated to alkaline phosphatase (Boehringer, Mannheim, Germany) and developed using nitroblue tetrazolium chloride and 5-bromo-4chloro-3'-indolyphosphate p-toluidine salt (Bio-Rad, Hercules, CA). Sections were visualized using phase contrast microscopy with an Axioskop 2 plus microscope (Zeiss, Germany). Images were recorded with the Axiovision 5 software (Zeiss).

Generation of a CuLCrV agroinoculation system. The CuLCrVA 1.5 mer was excised from pCuLCrVA1.5 by digestion with $\mathrm{XbaI}$ and $K p n \mathrm{I}$ and the 4.1-kb fragment was gel purified and ligated into the XbaI/KpnI-digested binary vector pGA482 (2). The resulting plasmid, pCuLCrVA1.5agro, was recovered from $E s$ cherichia coli (strain DH5 $\propto$ ) and transformed into competent Agrobacterium tumefaciens cells (strain C58) by electroporation. Transformants were identified based upon growth on Luria-Bertani media supplemented with tetracycline (tetracycline hydrochloride at $10 \mathrm{mg} / \mathrm{liter}$; SigmaAldrich, St. Louis) and the presence of CuLCrV DNA-A, which was confirmed by PCR with the degenerate DNA-A primers PAL1v1978 and PAR1c496 (30). The pCuLCrVB1.5agro construct was generated with the same restriction enzymes and method. The CuLCrVB1.5agro plasmid DNA then was transformed into A. tumefaciens (strain C58) and the presence of CuLCrV DNA-B was confirmed with the degenerate DNA-B primers PBL1v2040 and PCRc1 (30). 
For plant inoculations, Agrobacterium strains carrying pCuLCrVA1.5agro or CuLCrVB1.5agro were grown in liquid media supplemented with tetracycline (10 $\mathrm{mg} / \mathrm{liter}$ ) to a density of approximately 1 at $600 \mathrm{~nm}$. Shortly before inoculation, these cultures were mixed. Cucurbits (two-trueleaf stage), $N$. benthamiana (four- to sixtrue-leaf stage), and common bean (primary leaf stage) plants were inoculated beneath the shoot apex and at the first internode by needle puncture inoculation with a 10-cc syringe and 27-gauge sterile needle. Inoculated plants were maintained in a controlled-environment growth chamber or in a greenhouse as described above. Assessment of disease symptoms was made 10 to 21 days post inoculation (dpi) and, in selected plants, infection was confirmed by PCR analysis with CuLCrVspecific primers.

Germplasm screening for susceptibility to CuLCrV. Two types of agroinoculation experiments were performed, each with a different set of hosts. The first was a host range experiment performed with cantaloupe (Cucumis melo), honeydew melon (C. melo), watermelon (Citrullus lanatus), squash (Cucurbita pepo), pumpkin $(C$. maxima), common bean ( $P$. vulgaris cvs. Topcrop and Othello), and $N$. benthamiana. The second was a screen of various cantaloupe and honeydew melon cultivars (germplasm screening experiment). Agroinoculation was performed as previously described and watermelon (cv. Charleston grey) was used as a positive control. Infection was determined based upon symptom development 21 to $28 \mathrm{dpi}$. In both experiments, all symptomless plants were tested for infection by PCR analysis with $\mathrm{CuLCrV}$-specific primers. In the germplasm screening experiment, symptom severity was rated as follows: $1=$ no obvious symptoms; 2 = slight downcupping or crumpling or mild symptoms; 3 = obvious symptoms, including epinasty, crumple, mosaic, and interveinal chlorosis, and subsequent recovery from symptoms; and $4=$ severe symptoms, including stunted and distorted growth; leaf crumpling, curling, and chlorosis; and no observed recovery. Both experiments were repeated at least three times.

Sequencing, construction of phylogenetic trees, and analysis of recombination. DNA sequencing of the CuLCrV fulllength DNA-A and DNA-B clones in plasmid pZeroBlunt was performed using the primer walking method and ABI PRISM Dye Terminator Cycle Sequencing. Sequencing reactions were fractionated in $5 \%$ Long Ranger gels (Cambrex, NJ) and data were collected with ABI Prism 'A' sequencing software (Perkin-Elmer, Foster City, CA). DNA sequences were analyzed using the software of the Genetics Computer Group (version 10; Genetics Computer Group, Madison, WI), and the BLAST algorithm was used to compare sequences with those in the GenBank (1). Nucleotide sequences were aligned with PILEUP and phylogenetic analyses were performed with Phylogenetic Analysis Using Parsimony (PAUP; version 4.0b10; Sinaur Associates Inc., Sunderland, MA). Optimum trees and branch strengths were determined with a parsimony analysis using a heuristic search method, with random addition of taxa and 1,000 bootstrapped replicates. The resulting data was interpreted with TreeView (27).

The geminiviruses used for comparison and their corresponding GenBank accession numbers are: Abutilon mosaic virus (AbMV) (NC_001928 and NC_001929), African cassava mosaic virus (ACMV) (NC_001467 and NC_001468), Bean calico mosaic virus (BCaMV) (NC_003504 and NC_003505), BDMV (NC_001931 and NC_001930), Bean golden mosaic virus (BGMV) (NC_004042 and $\mathrm{NC}_{-}$ 004043), Bean golden yellow mosaic virus-Dominican Republic (BGYMV-DO) (NC_001439 and NC_001438), BGYMVGuatemala (BGYMV-GU) (M91604 and M91605), BGYMV-Mexico (BGYMVMX) (AF173555 and AF173556), Cabbage leaf curl virus (CaLCuV) ( $\mathrm{NC}_{-}$ 003866 and NC_003887), Chino del tomate virus-Tomato leaf crumple strain (CdTV-TLCr) (AF101476 and AF101478), Cotton leaf crumple virus (CLCrV) (NC_004580 and NC_004581), CuLCrVArizona isolate (CuLCrV-AZ) (AF256200 and AF327559), CuLCrV-California isolate (CuLCrV-CA) (NC_002984 and NC_002985), Tomato mosaic Havana virus (ToMHV-[Qui]) (Y14874 and Y14875), Pepper golden mosaic virus (PepGMV) (NC_004101 and NC_004096), Pepper hausteco yellow vein virus (PHYVV) (AY044162 and AY044163), Potato yellow mosaic virus (PYMV) (NC_001934 and NC_001935), Sida golden mosaic virus (SiGMV) (NC_002046 and NC_002047), Squash leaf curl virusPhilippines (SLCV-[PH]) (NC_005845 and NC_005846), Squash leaf curl virus (SLCV, previously extended host range strain of SLCV [SLCV-E]) (NC_001936 and NC_001937), Squash mild leaf curl virus (SMLCV, previously restricted host range strain of SLCV [SLCV-R]) (NC_004645 and NC_004646), Squash yellow mottle virus (SYMoV) (AY064391 and AF440790), Tomato mottle Taino virus (ToMoTV) (AF012300 and AF012301), and Tomato mottle virus (ToMoV) (NC_001938 and NC_001939).

Recombination analysis was performed with a modified version of the BOOTSCAN algorithm, RECSCAN (23), as available in the RDP2 computer program (24). A manual RECSCAN was performed with the CuLCrV DNA-A and DNA-B components as the potential recombinant sequences and the corresponding DNA-A and DNA-B components of BCaMV, SLCV, SMLCV, and SYMoV as potential parental sequences. The default settings of the RECSCAN analysis were used: window size was 100 , step size was 20 , and 100 bootstrap replicates were used; pairwise distances were used for comparison.

\section{RESULTS}

Field studies and host range. $\mathrm{CuLCrV}$ was detected in volunteer watermelon plants in the southern Imperial Valley in fall 1998 and partially characterized by winter 1999 (15). In field surveys of spring-planted melon conducted in 1999 , leaf crumpling and curling symptoms in cantaloupe plants in commercial fields and in cantaloupe and watermelon plants in experimental plots first were observed in July. Samples from these plants were consistently positive for geminivirus infection based on squash blot hybridization with the general begomovirus probe and PCR with degenerate begomovirus primers (14). Sequence analysis of selected PCRamplified DNA fragments revealed that these plants were infected with $\mathrm{CuLCrV}$. The fall survey (23 to 24 September) revealed widespread incidence of $\mathrm{CuLCrV}$ like symptoms (leaf crumple and curl symptoms on new growth [runners] and, in some cases, on older leaves) in all eight cantaloupe fields surveyed in the Imperial Valley at incidences ranging from 25 to $80 \%$. Plants in these fields also had high populations of whiteflies (B. tabaci Genn. biotype B). Begomovirus infection in symptomatic plants was confirmed by squash blot and PCR analyses, and sequence analysis of PCR-amplified fragments confirmed infection with $\mathrm{CuLCrV}$. In contrast, no geminivirus-like symptoms were observed in plants in commercial honeydew melon fields, nor was geminivirus infection detected in randomly selected symptomless plants. These results indicated that $\mathrm{CuLCrV}$ overwintered in the Imperial Valley and infected spring- and fall-planted cucurbits in 1999.

In 2000, CuLCrV-like symptoms appeared in spring-planted melon beginning in April, and $\mathrm{CuLCrV}$ infections were confirmed in six commercial cantaloupe fields and two experimental plots of watermelon (Table 1). Symptoms of begomovirus infection also were observed in plantings of pumpkin, squash, and zucchini and CuLCrV infection was confirmed in some of these plants. However, acorn and butternut squash plants were infected by SLCV or SMLCV (Table 1). In late summer and fall 2000, CuLCrV infections were detected in commercial cantaloupe fields throughout the Imperial Valley (including the Niland area) and in Yuma, $\mathrm{AZ}$; in watermelon fields in the Imperial Valley and Coolridge, AZ; and in squash plantings in the Coachella Valley, CA (Table 1). All of these fall-planted fields had high whitefly populations.

Very low incidences of CuLCrV infection were detected in both spring- and fall- 
planted melon in 2001 (Table 1). In spring 2002 , CuLCrV was detected only in watermelon plants in an experimental trial. However, by fall 2002, CuLCrV infections were detected in 11 commercial cantaloupe fields, in an experimental plot of squash in the Imperial Valley, and in commercial yellow crookneck squash (sometimes in
Table 1. Results of surveys for viral disease symptoms (stunted and distorted growth and leaf crumple, curl, and mosaic or mottle) in cucurbits in the Imperial and Coachella Valleys of California and detection of Cucurbit leaf crumple virus (CuLCrV), and Squash leaf curl virus (SLCV) or Squash mild leaf curl virus (SMLCV) infections ${ }^{\mathrm{a}}$

\begin{tabular}{|c|c|c|c|c|c|c|}
\hline \multirow[b]{2}{*}{ Date } & \multicolumn{2}{|c|}{ Melon } & \multicolumn{2}{|c|}{ Watermelon } & \multicolumn{2}{|c|}{ Squash $^{b}$} \\
\hline & $\mathrm{C}$ & $\mathbf{S}$ & $\mathrm{C}$ & $\mathbf{S}$ & $\mathrm{C}$ & $\mathbf{S}$ \\
\hline \multicolumn{7}{|l|}{2000} \\
\hline April & $3 / 3$ & NT & $1 / 1$ & NT & $\mathrm{NT}$ & NT \\
\hline May & $7 / 7$ & $0 / 7$ & $2 / 2$ & $0 / 2$ & $8 / 17$ & $5 / 17$ \\
\hline June & NT & NT & NT & NT & $0 / 10$ & $13 / 13$ \\
\hline July & NT & NT & NT & NT & NT & NT \\
\hline August & $3 / 4$ & $0 / 14$ & $13 / 14$ & $0 / 14$ & NT & NT \\
\hline September & $8 / 11$ & $0 / 11$ & $8 / 12$ & $0 / 12$ & $5 / 13$ & $9 / 13$ \\
\hline October & $5 / 10$ & $0 / 10$ & NT & NT & NT & NT \\
\hline November & $8 / 9$ & $0 / 9$ & NT & NT & NT & NT \\
\hline \multicolumn{7}{|l|}{2001} \\
\hline April & NT & NT & NT & NT & NT & NT \\
\hline May & NT & NT & NT & NT & NT & NT \\
\hline June & NT & NT & NT & NT & $0 / 1$ & $1 / 1$ \\
\hline July & $2 / 3$ & $1 / 3$ & NT & NT & NT & NT \\
\hline August & NT & NT & NT & NT & NT & NT \\
\hline September & NT & NT & NT & NT & $0 / 5$ & $5 / 5$ \\
\hline October & $7 / 9$ & $2 / 9^{c}$ & NT & NT & $0 / 3$ & $3 / 3$ \\
\hline November & NT & NT & NT & NT & NT & NT \\
\hline \multicolumn{7}{|l|}{2002} \\
\hline April & NT & NT & $3 / 10$ & $0 / 10$ & NT & NT \\
\hline May & NT & NT & NT & NT & NT & NT \\
\hline June & NT & NT & NT & NT & NT & NT \\
\hline July & NT & NT & NT & NT & NT & NT \\
\hline August & NT & NT & NT & NT & $0 / 10$ & $10 / 10$ \\
\hline September & NT & NT & $5 / 5$ & $0 / 5$ & $9 / 13$ & $5 / 13$ \\
\hline October & $64 / 84$ & $0 / 84$ & $3 / 4^{\mathrm{d}}$ & $0 / 4$ & $4 / 4$ & $4 / 4$ \\
\hline November & $19 / 19$ & $0 / 19$ & NT & NT & $10 / 10$ & $2 / 10$ \\
\hline \multicolumn{7}{|l|}{2003} \\
\hline April & NT & NT & NT & NT & NT & NT \\
\hline May & NT & NT & $2 / 3$ & $0 / 3$ & NT & NT \\
\hline June & $6 / 6$ & $0 / 6$ & NT & NT & NT & NT \\
\hline July & $10 / 10$ & $0 / 10$ & $4 / 4$ & $0 / 4$ & NT & NT \\
\hline August & NT & NT & NT & NT & NT & NT \\
\hline September & $4 / 4$ & $0 / 4$ & NT & NT & NT & NT \\
\hline October & $18 / 42$ & $0 / 42$ & NT & NT & $0 / 16$ & $12 / 16$ \\
\hline November & NT & NT & NT & NT & NT & NT \\
\hline
\end{tabular}

${ }^{a} \mathrm{C}=$ tested with $\mathrm{CuLCrV}$-specific primers and $\mathrm{S}=$ tested with SLCV-specific primers (these detect both SLCV and SMLCV). NT = none tested.

${ }^{\mathrm{b}}$ Includes pumpkin, yellow crookneck and zucchini.

c Mixed infection with CuLCrV.

d Volunteer plants.

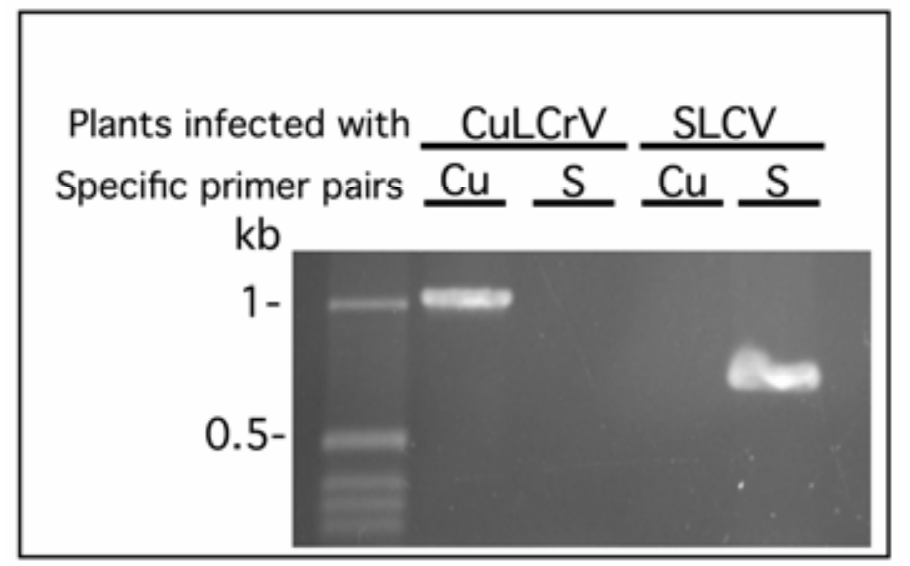

Fig. 1. Polymerase chain reaction-based detection of Cucurbit leaf crumple virus (CuLCrV) and Squash leaf curl virus (SLCV) in infected watermelon and squash leaves, respectively, with CuLCrVand SLCV-specific primers. The sizes of the amplified fragments are $705 \mathrm{bp}$ for SLCV or Squash mild leaf curl virus and 1,046 bp for CuLCrV. mixed infections with SLCV or SMLCV) and cantaloupe fields in the Coachella Valley (Table 1). The incidence of virus in these fields ranged from approximately 25 to $100 \%$, and whitefly populations were high in these fields. Economic losses were reported by squash growers in the Coachella Valley (J. Aguiar, personal communication). In 2003 surveys, CuLCrV infections were not detected in spring-planted melon; however, the virus appeared in fallplanted cantaloupe in the Imperial Valley (Table 1). In contrast to 2002, CuLCrV was not detected in the Coachella Valley in 2003.

The results of our surveys revealed a general pattern in which CuLCrV built up gradually, with spring-planted cucurbits having relatively low incidences of infection and fall-planted crops having higher incidences. This pattern also reflects the population dynamics of the whitefly vector, in which populations are relatively low in spring-planted melon and increase dramatically in the fall-planted crop. In terms of economic losses, CuLCrV had a minimal impact on watermelon and cantaloupe yields (E. T. Natwick and T. A. Turini, personal communication), whereas infections of squash sometimes led to reduced yields and distorted and abnormal fruit ( $\mathrm{J}$. Aguiar, personal communication). Observations of field-infected cantaloupe and watermelon plants revealed that, although plants initially developed severe symptoms of leaf crumpling and yellowing, subsequent growth showed greatly attenuated symptoms. Moreover, fruit produced by these "recovered" plants appeared normal. Thus, plants in commercial fields of cantaloupe and watermelon that initially showed severe symptoms of $\mathrm{CuLCrV}$ eventually "grew out" or recovered from these infections and still produced acceptable yields.

The CuLCrV host range study conducted at DREC revealed that the following hosts were susceptible (based upon development of symptoms and detection of CuLCrV DNA in representative plants): birdhouse gourd, blue Hubbard squash, cantaloupe, Cucurbita palmate, charentais melon, pumpkin, turks turban squash, yellow crookneck squash, and zucchini. The only susceptible noncucurbit was common bean (cv. Topcrop). Cucurbits that were not susceptible were acorn squash, ananas melon, butternut squash, casaba melon, galia melon, golden crenshaw melon, and honeydew melon. Nonsusceptible crops included cotton, pepper, soybean, and tomato.

Generation of CuLCrV- and SLCVspecific primers. To efficiently and specifically detect $\mathrm{CuLCrV}$ and differentiate it from SLCV, virus-specific primers were designed for use in the PCR. DNA-B hypervariable region (14) and $\mathrm{BC} 1 \mathrm{ORF}$ sequences of SLCV, CuLCrV, and other bipartite begomoviruses were aligned and 
divergent regions were identified (data not shown). These sequences were used to develop the following virus-specific PCR primers: CuLCrV V1324 (5'-TTCTTC TGGTAAAATATGGC-3') and CuLCrV C2370 (5'-CCGACGAGATATGTCAACG$\left.3^{\prime}\right)$; and SLCV V1837 (5'-GGAAGC AGCTCTTCTTCAATA-3') and SLCV C2542 (5'-GTGTACAAGAGCTAATGG GTT-3'). The specificity of these primers was evaluated in PCR tests with DNA extracts prepared from CuLCrV-infected watermelon leaves, SLCV-infected squash leaves, and uninfected watermelon leaves. The $\mathrm{CuLCrV}$-specific primers directed the amplification of the expected approximately $1.0-\mathrm{kb}$ fragment from extracts of $\mathrm{CuLCrV}$-infected leaves and no fragments from extracts of SLCV-infected or uninfected plants; whereas the SLCV-specific primers directed the amplification of the expected approximately $0.7-\mathrm{kb}$ fragment from extracts of SLCV-infected plants and no fragments from CuLCrV-infected or uninfected plants (Fig. 1). Sequencing of these PCR-amplified fragments confirmed that the correct template molecules were being amplified by these primers.

Infectivity of the cloned CuLCrV DNA-A and DNA-B components. Putative full-length $\mathrm{CuLCrV}$ DNA-A and DNA-B fragments were generated by PCR with overlapping primers, and these fragments were cloned to generate pCuLCrVA and $\mathrm{pCuLCrVB}$, respectively. Watermelon (cv. Charleston grey) and common bean seedlings (cv. Topcrop) bombarded with the putative-full length $\mathrm{CuLCrV}$ DNA-A and DNA-B, released from pCuLCrVA and pCuLCrVB, developed symptoms including stunted and distorted growth and leaf crumple, curl, and chlorosis approximately 7 to $10 \mathrm{dpb}$ (Fig. 2A). Furthermore, the symptoms of disease in these bombarded plants were indistinguishable from those observed in the field. CuLCrV infection in these plants was confirmed by PCR analysis with general begomovirus or CuLCrVspecific primers. No disease symptoms were observed in plants bombarded with gold particles alone (Fig. 2B). These results established the infectivity of the fulllength CuLCrV DNA-A and DNA-B clones.

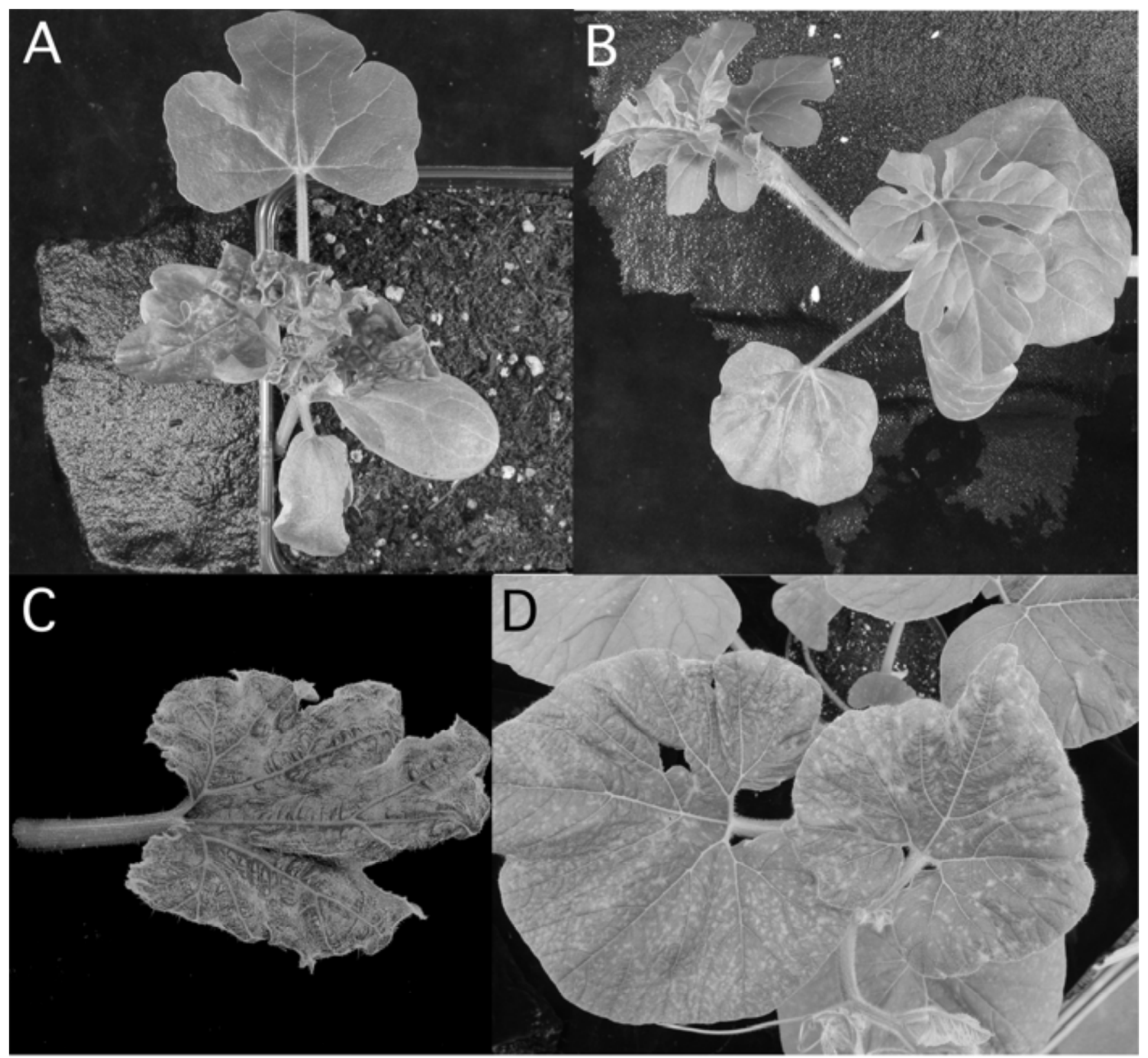

Fig. 2. Disease symptoms in selected cucurbits following particle bombardment inoculation with the cloned DNA-A and DNA-B components of Cucurbit leaf crumple virus (CuLCrV) or gold particles only. A, Watermelon seedlings (cv. Charleston grey), bombarded with CuLCrV DNA-A and DNA-B, 12 days post bombardment (dpb). B, Watermelon seedlings bombarded with gold particles alone. C, Zucchini leaf (cv. Elite) from a plant bombarded with CuLCrV DNA-A and DNA-B (16 dpb). D, Pumpkin plant (cv. Big Max) bombarded with CuLCrV DNA-A and DNA-B (12 dpb). 
To avoid having to release the fulllength clones from the associated cloning vectors before bombardment, multimeric DNA-A (pCuLCrVA1.5) and DNA-B (pCuLCrVB1.5) clones were generated, which do not require this step. The DNA-A and DNA-B multimers were introduced into cantaloupe, watermelon, pumpkin, zucchini, two cultivars of common bean, and $N$. benthamiana by particle bombardment. The results of these experiments are shown in Table 2. By approximately 10 $\mathrm{dpb}$, stunted growth and leaf crumple, curl, and chlorosis symptoms developed in

Table 2. Results of inoculation experiments performed in different host plants following sap-inoculation with Cucurbit leaf crumple virus $(\mathrm{CuLCrV})$ or particle bombardment or agroinoculation with infectious cloned CuLCrV DNA-A and DNA-B components

\begin{tabular}{llc}
\hline $\begin{array}{l}\text { Virus, } \\
\text { inoculation method }\end{array}$ & \multicolumn{1}{c}{ Host } & $\begin{array}{c}\text { No. infected/ } \\
\text { no. inoculated } \\
\text { (\% infected) }\end{array}$ \\
\hline CuLCrV & & \\
Particle bombardment & Cucurbita pepo, zucchini (cv. Elite) & $42 / 48(88)$ \\
& C. maxima, pumpkin (cv. Big Max) & $21 / 30(70)$ \\
& Citrullus lanatus, watermelon (cv. Charleston grey) & $49 / 51(96)$ \\
& Cucumis melo, cantaloupe (cv. Laredo) & $60 / 66(91)$ \\
& Phaseolus vulgaris, common bean (cv. Topcrop) & $30 / 48(63)$ \\
Agroinoculation & P. vulgaris (cv. Othello) & $0 / 52(0)$ \\
& Nicotiana benthamiana & $17 / 53(32)^{\mathrm{b}}$ \\
& C. lanatus (cv. Charleston grey) & $29 / 32(90)$ \\
Sap transmission & P. vulgaris (cv. Topcrop) & $18 / 35(51)$ \\
& P. vulgaris (cv. Othello) & $0 / 35(0)$ \\
BDMV & N. benthamiana & $3 / 24(13)^{\mathrm{b}}$ \\
Sap transmission & C. pepo (cv. Small sugar) & $0 / 25(0)$ \\
& N. vulgaris (cv. Topcrop) & $0 / 34(0)$ \\
& C. penthamiana (cv. Small sugar) & $0 / 22(0)$ \\
& P. vulgaris (cv. Topcrop) & $0 / 13(0)$ \\
& N. benthamiana & $16 / 17(94)$ \\
& & $12 / 12(100)$ \\
\hline
\end{tabular}

a Assessment of CuLCrV infection was made 10 to 21 days post inoculation based upon appearance of diagnostic disease symptoms or results of polymerase chain reaction analyses with CuLCrV-specific primers. Means are of at least three independent experiments.

${ }^{\mathrm{b}}$ Symptomless infection.

${ }^{\mathrm{c}}$ Bean dwarf mosaic virus (BDMV) was used as a positive control for sap transmission experiments.

bombarded cantaloupe and watermelon seedlings (Table 2, Fig. 2A). Symptoms were most severe in the second and third true leaves and became progressively milder in newly emerging leaves. By approximately $20 \mathrm{dpb}$, newly emerging leaves had few, if any, obvious symptoms. In pumpkin and zucchini, symptoms were also severe and included stunted growth and leaf crumple, curl, and leaf yellowing and mottling (Fig. 2C). In contrast to melon and watermelon, symptoms did not attenuate over time in these Cucurbita spp. In common bean (cv. Topcrop), symptoms first appeared on primary leaves and included yellow spots and mottling. Emerging trifoliolate leaves showed leaf crumpling, curling, and mottling symptoms; these symptoms became attenuated over time. No symptoms developed in cv. Othello seedlings bombarded with $\mathrm{CuLCrV}$ cloned DNA, nor was CuLCrV DNA detected in these plants by PCR. No obvious symptoms developed in $N$. benthamiana seedlings bombarded with the cloned CuLCrV DNAs; however, viral DNA was detected in approximately $30 \%$ of inoculated plants (Table 2). No symptoms or viral DNA were detected in any plants bombarded with gold particles alone or in plants bombarded with the DNA-A or DNA-B multimers alone (data not shown).

Attempts to infect small sugar pumpkin, common bean (cv. Topcrop), or N. benthamiana with CuLCrV by sap inoculation were unsuccessful, and viral DNA was not detected in newly emerged leaves of any
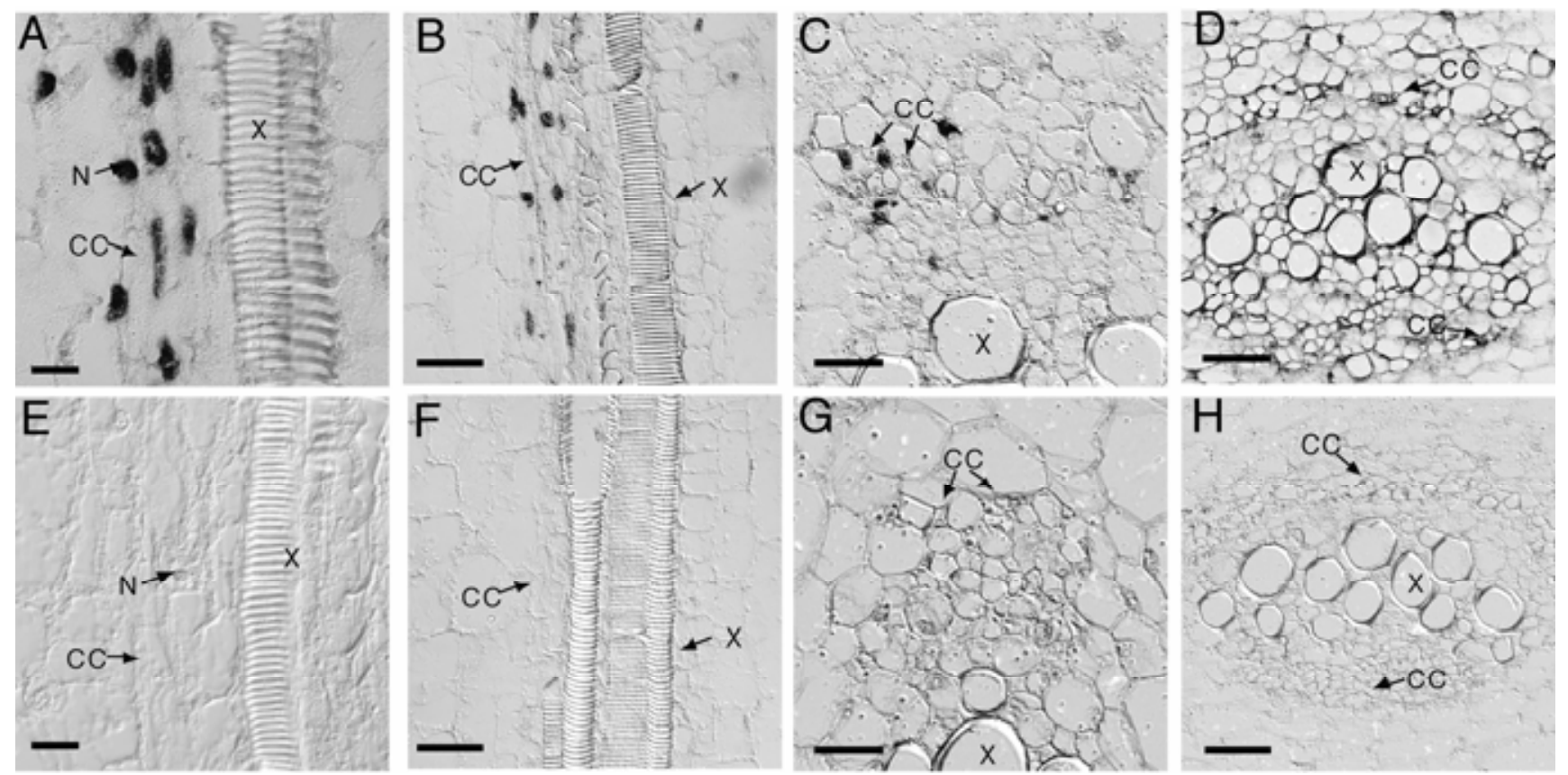

Fig. 3. Localization of Cucurbit leaf crumple virus $(\mathrm{CuLCrV})$ in leaves of infected zucchini plants. Sections were prepared from CuLCrV-infected zucchini approximately 4 weeks after inoculation. A, Longitudinal section of an infected petiole probed with antibodies raised against the begomovirus capsid protein (CP) and showing signal localized to nuclei of companion cells (CC). B, Lower magnification of a longitudinal section of an infected petiole probed with CP antiserum. C, Cross-section of an infected petiole probed with CP antiserum showing signal localized to CC nuclei. D, In situ localization of CuLCrV DNA associated with phloem cells. E, F, and G, Immunolocalization controls: longitudinal and cross-sections of uninfected plants probed with pre-immune antiserum. H, In situ hybridization control; a cross-section from an uninfected plant probed with the digoxigenin-labeled CuLCrV CP RNA transcript. Bars in A and $\mathrm{E}$ represent $25 \mu \mathrm{m}$; bars in $\mathrm{C}, \mathrm{D}, \mathrm{F}, \mathrm{G}$, and $\mathrm{H}$ represent $50 \mu \mathrm{m}$. Abbreviations: $\mathrm{CC}=$ companion cells, $\mathrm{N}=$ nucleus, and $\mathrm{X}=\mathrm{xylem}$. 
sap-inoculated plants. In parallel experiments with BDMV, high rates (94 to $100 \%$ ) of infection in sap-inoculated common bean and $N$. benthamiana plants were consistently obtained (Table 2 ). Immunolocalization experiments and in situ hybridization experiments performed with leaves and petioles of $\mathrm{CuLCrV}$-infected zucchini plants revealed the presence of the virus only in phloem-associated cells (Fig. 3A, B, C, and D); both $\mathrm{CP}$ and viral DNA was detected in mature companion cells and sieve elements, whereas no signal was detected in tissues of equivalent uninfected plants (Fig. 3E, F, G, and H). These results indicate that $\mathrm{CuLCrV}$ is a phloemlimited bipartite begomovirus. This finding is also fully consistent with the inability to sap transmit CuLCrV.

Development of a CuLCrV agroinoculation system. The CuLCrV DNA-A and DNA-B multimeric constructs each were cloned into the binary vector pGA482, and these plasmids were transformed into $A$. tumefaciens (strain $\mathrm{C} 58$ ) to generate $\mathrm{CuL}$ CrVA1.5agro and CuLCrVB1.5agro, re- spectively. Seedlings of zucchini (cv. Elite), common bean (cv. Topcrop), watermelon (cv. Charleston grey), cantaloupe (cv. Laredo), and pumpkin (cv. Big Max) agroinoculated with CuLCrVA1.5agro and CuLCrVB1.5agro developed symptoms of stunted and distorted growth and leaf crumple, curl, and chlorosis (Fig. 4A and $\mathrm{B}$, and Table 2). These symptoms were indistinguishable from those observed in plants following particle bombardment inoculation or infected plants in the field. Equivalent seedlings inoculated with $A$.

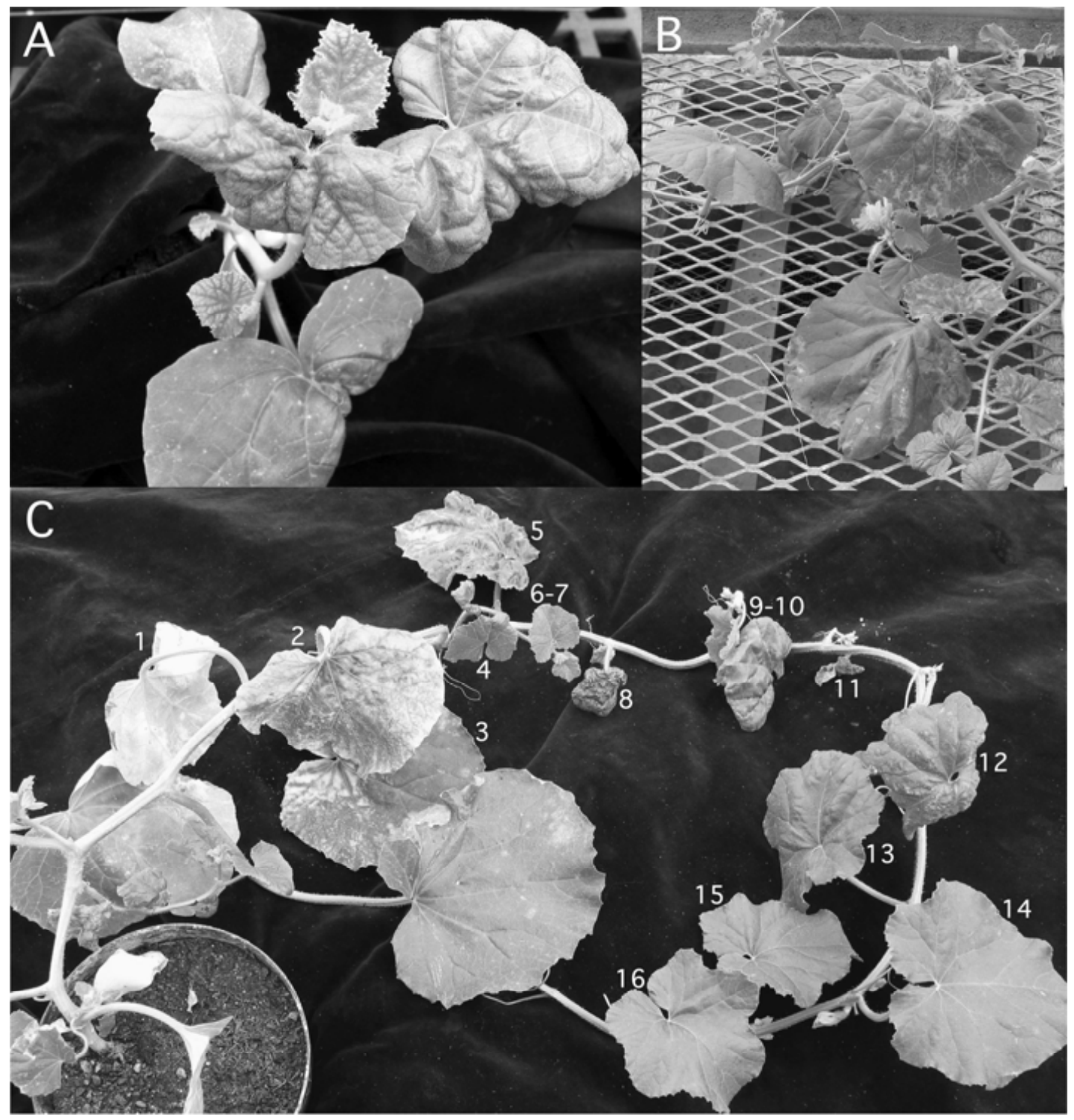

Fig. 4. Disease symptoms observed in cantaloupe (Cucumis melo) following agroinoculation with the cloned DNA-A and DNA-B components of Cucurbit leaf crumple virus. Cultivars A, Laredo, 14 days post inoculation (dpi); B, Ocotillo, $28 \mathrm{dpi}$; and $\mathbf{C}$, Goldmine, 42 dpi (1 to 16 indicates older to younger leaves, respectively). 
tumefaciens harboring the pGA482 vector alone did not develop symptoms. Agroinoculation provided high rates of infection in Charleston grey watermelon $(87 \%)$ and Elite zucchini (84\%), with lower rates in cantaloupe (up to $63 \%$ and cultivar dependent) (Table 3). Cucurbit and bean seedlings agroinoculated with $\mathrm{CuLCrV}$ developed symptoms slightly later (10 to 14 days) than plants inoculated by particle bombardment ( 7 to 10 days). Common bean (cv. Othello) seedlings agroinoculated with $\mathrm{CuLCrV}$ did not develop symptoms, nor was viral DNA detected in newly emerged leaves of any of these plants (Table 2). $N$. benthamiana seedlings agroinoculated with $\mathrm{CuLCrV}$ displayed very mild or no symptoms; however, $\mathrm{CuLCrV}$ DNA was detected in newly emerged leaves of $13 \%$ of agroinoculated plants (Table 2). CuLCrV infection was confirmed in representative symptomatic plants and by PCR with CuLCrV-specific primers (data not shown).

Germplasm screening. Agroinoculation next was used to screen a range of cantaloupe and honeydew melon cultivars for susceptibility to CuLCrV. The results are summarized in Table 3.

Overall, the highest rates of infection and most severe initial symptoms were obtained for watermelon cultivars (Table $3)$. High rates of infection and severe symptoms also were obtained for different types of squash, including zucchini and pumpkin; however, $\mathrm{CuLCrV}$ was not highly infectious in butternut squash $(\mathrm{Cu}$ curbita moshata), inducing symptoms in the terminal growth of only one of seven inoculated plants. The infectivity of $\mathrm{CuLCrV}$ in cantaloupe was cultivar dependent (Table 3). Honeydew melon plants agroinoculated with $\mathrm{CuLCrV}$ generally were symptomless, although a few plants developed very mild symptoms and $\mathrm{CuLCrV}$ infection was detected in leaves of these plants (Table 3). Similarly, agroinoculated cucumber seedlings did not develop symptoms, although symptomless infections were detected in two of four cultivars (Table 3 ). In general, these results were consistent with those from the host range study conducted in the field.

Low to moderate rates of infection (12 to $63 \%$ ) were obtained in the majority of cantaloupe cultivars evaluated (Table 3 ), and symptoms ranged from mild to moderate. Infected plants of all cultivars showed the recovery phenotype in which severe symptoms initially were observed in the first to third true leaves emerging after inoculation (10 to $14 \mathrm{dpi}$ ), followed by an attenuation of symptoms in leaves emerging later (Fig. 4C). A few of the cantaloupe cultivars were highly resistant (e.g., HMX0584, MR1, Nito, and Rocket). Honeydew melon cultivars generally were highly resistant, although a small proportion of plants of some cultivars displayed very mild symptoms or had symptomless infections (Table 3).
Table 3. Results of inoculation experiments in various cucurbit hosts using agroinoculation of infectious cloned Cucurbit leaf crumple virus (CuLCrV) DNA-A and DNA-B components

\begin{tabular}{|c|c|c|}
\hline Cucurbit, species, cultivar ${ }^{a}$ & $\begin{array}{l}\text { No. infected/ } \\
\text { no. inoculated } \\
(\% \text { infected })^{b}\end{array}$ & Symptoms ${ }^{c}$ \\
\hline \multicolumn{3}{|l|}{ Cantaloupe } \\
\hline \multicolumn{3}{|l|}{ Cucumis melo } \\
\hline Caravelle & 2/17 (12) & MiChls, EaChls \\
\hline Cruiser & $2 / 14(14)$ & Ep, LCr, MiChls, Chl \\
\hline Dewlicious & $0 / 13(0)$ & $\ldots$ \\
\hline Don Carlos & 2/12 (17) & Ep, LCr, MiChls, Chl \\
\hline Durango & 0/11 (0) & $\ldots$ \\
\hline Esteem & $6 / 15(40)$ & Ep, LCr, Mo, Chl \\
\hline Gold express & $5 / 17(29)$ & Ep, LCr, MiChls, Chl \\
\hline Gold mine & $8 / 19(42)$ & Ep, LCr, Mo, Chl \\
\hline Gold rush & $4 / 20(20)$ & Ep, LCr, MiChls, Chl \\
\hline HMX 0584 & $0 / 15(0)$ & $\ldots$ \\
\hline HMX 8586 & $3 / 12(25)$ & Ep, LCr, MiChls, Chl \\
\hline Hymark & $7 / 15(47)$ & Ep, LCr, Mo, Chl \\
\hline Impac & $4 / 14(29)$ & Ep, LCr, MiChls, Chl \\
\hline Imperial 45 & $0 / 15(0)$ & \\
\hline Iroquois & $1 / 10(10)$ & Ep, LCr, MiChls, Chl \\
\hline Laredo & $11 / 24(46)$ & Ep, LCr, MiChls, Chl \\
\hline Laredo & $12 / 19(63)$ & Ep, LCr, Mo, Chl \\
\hline Mission & $4 / 16(25)$ & Ep, LCr, MiChls, Chl \\
\hline Montagua & 2/12 (17) & Ep, LCr, MiChls, Chl \\
\hline MR1 & $0 / 12(0)$ & $\ldots$ \\
\hline Nito & $0 / 18(0)$ & $\ldots$ \\
\hline Ocotillo & $6 / 20(30)$ & Ep, LCr, MiChls, Chl \\
\hline Olympic Gold & 4/14 (29) & Ep, LCr, Mo, Chl \\
\hline Oro Rico & 2/16 (13) & Ep, MiChls, EaChl \\
\hline Rocket & $0 / 17(0)$ & \\
\hline SME 0031 & $4 / 16(25)$ & Ep, LCr, MiChls, Chl \\
\hline Sol Real & 2/17 (12) & Ep, MiChls, Chl \\
\hline Sparkle & $2 / 15(13)$ & Ep, LCr, MiChls, Chl \\
\hline Valley Gold & 2/12 (17) & Ep, LCr, MiChls, Chl \\
\hline Valley Pac & $8 / 16(50)$ & Ep, LCr, Mo, Chl \\
\hline Western Express & $7 / 16(44)$ & Ep, LCr, Mo, Chl \\
\hline XME 0069 & $5 / 16(31)$ & Ep, LCr, MiChls, Chl \\
\hline XME 0164 & $3 / 16(19)$ & Ep, LCr, MiChls, Chl \\
\hline Zodiac & $6 / 23(26)$ & Ep, LCr, MiChls, Chl \\
\hline \multicolumn{3}{|l|}{ Casaba } \\
\hline \multicolumn{3}{|l|}{ C. melo } \\
\hline Golden beauty & $0 / 15(0)$ & $\ldots$ \\
\hline \multicolumn{3}{|l|}{ Cucumber } \\
\hline \multicolumn{3}{|l|}{ C. sativus } \\
\hline Picklebush & $0 / 12(0)$ & $\ldots$ \\
\hline Straight 8 & $0 / 16(0)$ & $\ldots$ \\
\hline Vlasstar & $5 / 16(31)$ & NS \\
\hline Sweetslice & $1 / 18(8)$ & NS \\
\hline \multicolumn{3}{|l|}{ Honeydew } \\
\hline \multicolumn{3}{|l|}{ C. melo } \\
\hline Honeydew & $3 / 12(25)$ & NS/ MiChls \\
\hline Seminis PX 3912988 & $0 / 11(0)$ & $\ldots$ \\
\hline Emerald & 2/12 (17) & Mot, Chl \\
\hline Honey Ace & 2/17 (12) & NS \\
\hline Honey Brew & $0 / 14(0)$ & $\ldots$ \\
\hline Honey Gold & $2 / 18(11)$ & Mot \\
\hline Mega Brew & $7 / 22(32)$ & Mot \\
\hline Morning Ice & $2 / 19(11)$ & NS \\
\hline Santa Fe & $0 / 12(0)$ & $\ldots$ \\
\hline Saturno & $0 / 15(0)$ & $\ldots$ \\
\hline Silver World & $0 / 16(0)$ & $\ldots$ \\
\hline Twilight & $0 / 12(0)$ & $\ldots$ \\
\hline \multicolumn{3}{|l|}{ Pumpkin } \\
\hline \multicolumn{3}{|l|}{ Cucurbita maxima } \\
\hline Big Max & $9 / 15(60)$ & $\begin{array}{r}\text { Severe Ep, Mo, St, severe LCr, EaChl, EaChls } \\
\text { (continued on next page) }\end{array}$ \\
\hline
\end{tabular}

${ }^{a}$ Cucurbit type, species, and cultivar name.

${ }^{b}$ Assessment of CuLCrV infection was made 13 to 15 days post inoculation based upon appearance of diagnostic disease symptoms or results of polymerase chain reaction analyses with CuLCrV-specific primers. Means are of at least three independent experiments.

c Symptoms are abbreviated as follows: $\mathrm{Chl}=$ interveinal chlorosis, $\mathrm{EaChl}=$ early leaf interveinal chlorosis, Chls = chlorotic spots, EaChls = early leaf chlorotic spots, $\mathrm{Ep}=$ epinasty, $\mathrm{LCr}=$ leaf crumple, $\mathrm{MiChls}=$ mild chlorotic spots, $\mathrm{Mo}=$ mosaic, Mot $=$ mottle, $\mathrm{NS}=$ no symptoms, and $\mathrm{St}=$ stunting. 
Table 3. (continued from preceding page)

\begin{tabular}{|c|c|c|}
\hline Cucurbit, species, cultivar ${ }^{\mathrm{a}}$ & $\begin{array}{l}\text { No. infected/ } \\
\text { no. inoculated } \\
(\% \text { infected })^{b}\end{array}$ & Symptoms ${ }^{c}$ \\
\hline \multicolumn{3}{|l|}{ Squash } \\
\hline \multicolumn{3}{|l|}{ C. реро } \\
\hline Lolita & $2 / 16(13)$ & Ep, Mo, St, LCr, Chl, EaChls \\
\hline Elite & $27 / 32(84)$ & Ep, Mo, St, LCr, Chl, EaChls \\
\hline Burpee Fordhook Zucchini & $6 / 13(46)$ & Ep, Mo, St, LCr, Chl, EaChls \\
\hline Early golden summer crookneck & $9 / 15(60)$ & Ep, Mo, St, LCr, Chl, EaChls \\
\hline Early acorn hybrid & $11 / 14(79)$ & Ep, Mo, St, LCr, Chl, EaChls \\
\hline Early prolific straightneck & $11 / 14(79)$ & Severe Ep, Mo, St, LCr, EaChl \\
\hline Black beauty zucchini & $7 / 12(58)$ & Severe Ep, Mo, St, LCr, EaChl \\
\hline Jack'o Lantern pumpkin & $10 / 13(77)$ & Severe Ep, Mo, St, severe LCr, EaChl \\
\hline Small sugar pumpkin & $12 / 15(80)$ & Ep, Mo, St, LCr, Chl, EaChl, EaChls \\
\hline \multicolumn{3}{|l|}{ Squash } \\
\hline \multicolumn{3}{|l|}{ C. moschata } \\
\hline Waltham butternut & $1 / 14(7)$ & Ep, Mo, St, LCr, Chl, EaChls \\
\hline \multicolumn{3}{|l|}{ Squash } \\
\hline \multicolumn{3}{|l|}{ C. maxima } \\
\hline Pink banana squash & $4 / 12(33)$ & Severe Ep, Mo, St, LCr, EaChl \\
\hline Buttercup squash & $0 / 14(0)$ & $\ldots$ \\
\hline \multicolumn{3}{|l|}{ Watermelon } \\
\hline \multicolumn{3}{|l|}{ Citrullus lanatus } \\
\hline Sugarbaby & $9 / 11(82)$ & Ep, Chls, Chl, St, LCr \\
\hline Crimson sweet & $10 / 13(77)$ & Ep, Chls, Chl, St, LCr \\
\hline Charleston grey & $13 / 15(87)$ & Severe Ep, Chls, Chl, St, LCr \\
\hline
\end{tabular}

Sequence analysis of infectious DNA$A$ and DNA-B clones of CuLCrV. The CuLCrV DNA-A and DNA-B components were 2,632 (GenBank accession no. NC_002984) and 2,600 nucleotides (nt) (GenBank accession no. NC_002985), respectively. The DNA-A and DNA-B sequences share a CR of approximately 194 nt, which is $98 \%$ identical. This CR sequence contains the characteristic inverted repeat capable of forming a stemloop structure, with the highly conserved nanonucleotide sequence, TAATATTAC, located within the loop sequence. The sequence of the replication-associated protein high affinity binding sites is GGTGTCCTGGTGT (pentanucleotide binding sites in bold).

An analysis for ORFs or genes encoding proteins $>10 \mathrm{kDa}$ revealed five ORFs for CuLCrV DNA-A, corresponding to the bipartite begomovirus genes AV1, AC1, $\mathrm{AC} 2, \mathrm{AC} 3$, and AC4. Two ORFs were detected for CuLCrV DNA-B, corresponding to the bipartite begomovirus genes $\mathrm{BV} 1$ and $\mathrm{BC} 1$. Thus, the genome organization of this California isolate of $\mathrm{CuLCrV}$ is similar to that of other bipartite whiteflytransmitted begomoviruses (31).

Comparisons made with the entire DNA-A and DNA-B sequences or sequences of individual ORFs and the CR against other characterized begomoviruses revealed the highest level of sequence identity with an isolate of $\mathrm{CuLCrV}$ from Arizona (CuLCrV-AZ; >99\%). Thus, our isolate is designated as a California isolate of $\mathrm{CuLCrV}$ (CuLCrV-CA). The next highest sequence identity was with SMLCV, with $83 \%$ identity for the DNA-A component and $68 \%$ identity for the DNA-B component. The next most similar virus was BCaMV, with $79 \%$ identity for the
DNA-A component and 64\% identity for the DNA-B component.

Phylogenetic analyses were performed with the $\mathrm{CuLCrV} \mathrm{AC1}$ and $\mathrm{BC} 1$ nucleotide sequences. The AC1 sequence was chosen because it is relatively divergent (i.e., compared with the $\mathrm{CP}$ gene) and often involved in recombination events, whereas the $\mathrm{BC} 1$ sequence would reflect pseudorecombination events. Because CuLCrV was placed in the SLCV cluster of Western Hemisphere bipartite begomoviruses in both analyses (Fig. 5), there was no evidence of recombination or pseudorecombination in the evolution of CuLCrV-CA. However, a RECSCAN recombination analysis did reveal evidence of recombination with SMLCV in the DNA-A component (Fig. 6). Here, an approximately 138bp region of the $\mathrm{CuLCrV} \mathrm{AC} 1 \mathrm{ORF}$, including the first $103 \mathrm{bp}$ of the AC4 ORF, had between 97 and $99 \%$ bootstrap support for recombination with SMLCV (Fig. 6A). Consistent with this result, the SMLCV and $\mathrm{CuLCrV} \mathrm{AC} 1$ sequences in this region are $93 \%$ identical, with a 58-nt portion of AC4 having $100 \%$ identity. In contrast, this region was only $80 \%$ identical between $\mathrm{CuLCrV}$ and SLCV. There was a lower level of support (approximately 70\% bootstrap support) for recombination with SMLCV in a portion of the CuLCrV AV1 ORF (Fig. 6A). No evidence of recombination in the CuLCrV DNA-B was detected (Fig. 6B).

\section{DISCUSSION}

In this report, we present the biology and complete characterization of a California isolate of $\mathrm{CuLCrV}$, a newly emergent cucurbit-infecting begomovirus in the southwestern United States and northern Mexico $(5,15)$. The development of leaf crumple and chlorosis in watermelon seedlings inoculated with the infectious CuLCrV-CA DNA-A and DNA-B clones complete Koch's postulates for this virus. These results confirm that $\mathrm{CuLCrV}$ caused these symptoms in the watermelon volunteers observed in the Imperial Valley in fall 1998 and are in agreement with those of Brown et al. (5) for an isolate from Arizona (CuLCrV-AZ).

Following the identification of $\mathrm{CuLCrV}$ in the Imperial Valley, two important questions emerged: (i) would it become established in southern California and (ii) what would the impact be on commercial melon production. The results of 4 years of field surveys in the Imperial Valley showed that $\mathrm{CuLCrV}$ did become established in this agricultural production area and that it infected and caused symptoms in cantaloupe, squash, and watermelon but not honeydew melon. The virus has since been detected in the Coachella Valley of California, and in Arizona and northern Mexico (5; this study). More recently, CuLCrV was reported from Florida, where it may have been introduced via infected watermelon transplants from the southwestern United States (J. E. Polston, personal communication). The finding that $\mathrm{CuLCrV}$ infection generally was lower in spring versus fall melon probably reflects inefficient overwintering, followed by gradual build-up during the spring and fall melon seasons. This pattern reflects the build-up of populations of the whitefly vector, which play a key role in the spread of the virus. Although the means by which $\mathrm{CuLCrV}$ overwinters in the Imperial Valley were not determined, infected volunteer cucurbits are a possibility.

The other key observation from field surveys was that cantaloupe and watermelon plants recovered from $\mathrm{CuLCrV}$ infection. Here, the initial severe symptoms that developed shortly after inoculation became attenuated and, in commercial fields, such plants provided acceptable yields. Taken together with the fact that honeydew melon is highly resistant to $\mathrm{CuLCrV}$, the virus has had relatively little economic impact on melon production in the Imperial Valley. In contrast, the recovery phenotype was not observed in Cucurbita spp. (e.g., squash, pumpkin, and zucchini) and economic losses were experienced in squash fields in the Coachella Valley (there is no commercial production of squash in the Imperial Valley). The recovery phenotype in cantaloupe and watermelon infected with $\mathrm{CuLCrV}$ also was observed under experimental conditions, indicating that it is a bona fide response to viral infection rather than a phenomenon associated with conditions in the field. Although the exact nature of this recovery phenotype is not known, it bears resemblance to previously described instances of plants recovering from viral infection $(6,8)$. 
Results of the field plot study at the DREC, where plants were presumably inoculated via viruliferous whiteflies, indicated that $\mathrm{CuLCrV}$ primarily infects cucurbits (melon, watermelon, and squash), as well as common bean. $\mathrm{CuLCrV}$ did not infect a number of cucurbits, including ananas, casaba, galia, and honeydew melon; cucumber; and butternut squash. Host range studies using infectious $\mathrm{CuLCrV}$ clones, delivered via particle bombardment and agroinoculation, were consistent with results of field studies and established that watermelon and various squash types (e.g., pumpkin, yellow crookneck, and zucchini) were most susceptible, whereas cantaloupe was moderately susceptible and butternut squash, cucumber, and honeydew melon were resistant.

Agroinoculation and particle bombardment experiments confirmed that $\mathrm{CuLCrV}$ was infectious in common bean (cv. Topcrop); and it induced leaf crumple, curl, and mottle symptoms that are similar to those induced by BDMV. However, whereas $\mathrm{CuLCrV}$ was highly infectious in the large-seeded cv. Topcrop (from the Andean common bean gene pool), it did not infect the medium-seeded cv. Othello (from the Middle American gene pool). This suggests that CuLCrV may exhibit a differential pathogenicity in common bean similar to that shown by BDMV, which infects and causes symptoms in Andean but not Middle American genotypes
$(25,35,39)$. Interestingly, in contrast to most begomoviruses characterized to date, $\mathrm{CuLCrV}$ was poorly infectious in N. benthamiana, inducing only a symptomless infection in a relatively small proportion of plants.

A number of methods were evaluated for screening cucurbit germplasm for $\mathrm{CuLCrV}$ resistance. Like many whiteflytransmitted begomoviruses, CuLCrV was not sap transmissible, and the finding that $\mathrm{CuLCrV}$ is phloem-limited in zucchini was fully consistent with the lack of sap transmissibility. High rates of $\mathrm{CuLCrV}$ infection in cucurbits and common bean were obtained with the infectious cloned $\mathrm{CuLCrV}$ DNAs delivered via particle bombardment and agroinoculation. Particle

A
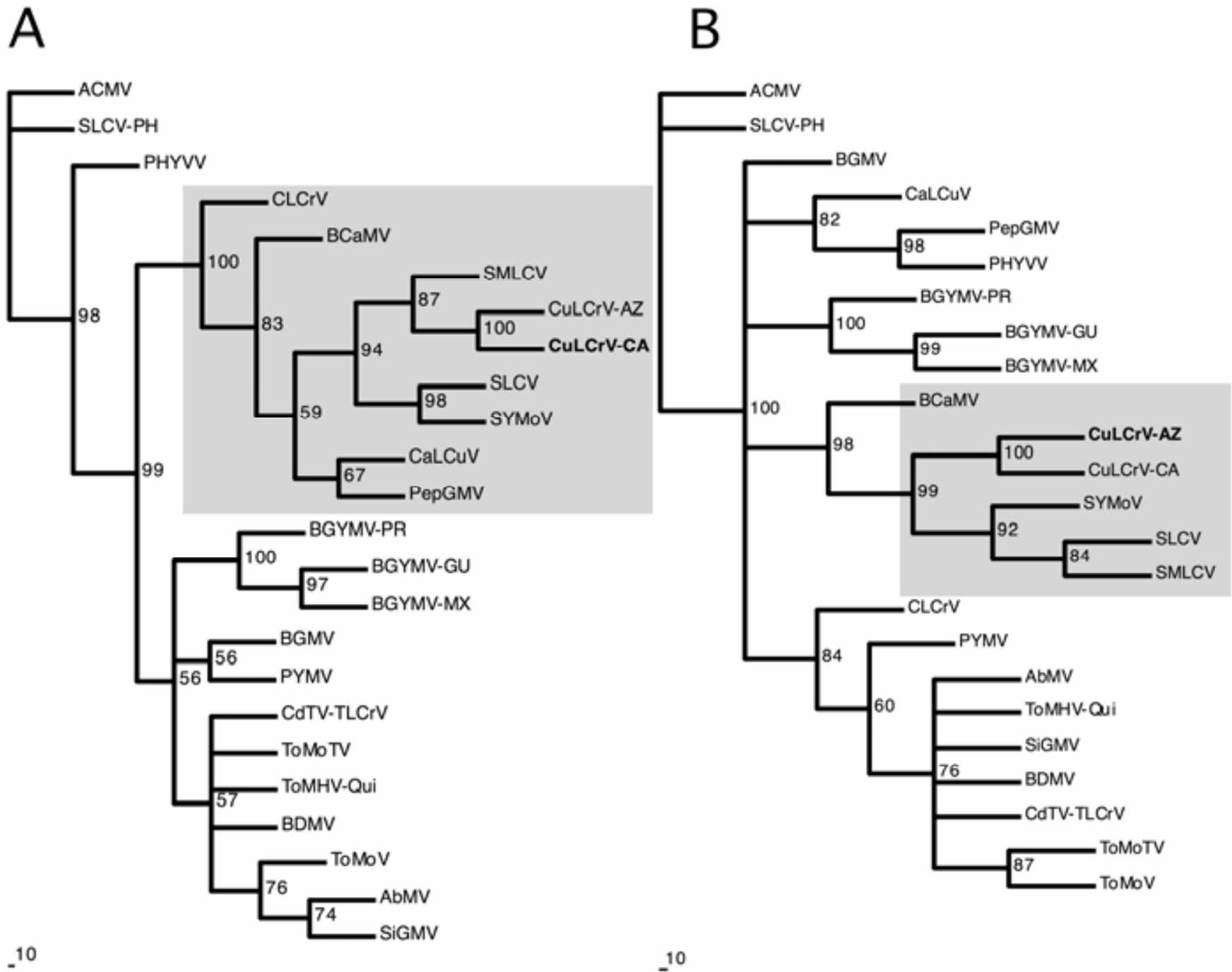

Fig. 5. Phylogenetic consensus trees showing the relationship of an isolate of Cucurbit leaf crumple virus from the Imperial Valley of California (CuLCrVCA) with other bipartite begomoviruses based on alignments of the A, AC1 open reading frame (ORF), and B, BC1 ORF nucleotide sequences. Phylogenetic analyses were performed with PAUP (Phylogenetic Analysis Using Parsimony) version 4.0 b10 using heuristic search. Branch strengths were evaluated by constructing 1,000 trees in bootstrap analysis by stepwise addition at random. Bootstrap values $(>50 \%)$ are shown above the horizontal line. Trees were rooted with African cassava mosaic virus (ACMV, Kenyan isolate). AbMV = Abutilon mosaic virus; $\mathrm{BCaMV}=$ Bean calico mosaic virus; $\mathrm{BDMV}=$ Bean dwarf mosaic virus; BGMV = Bean golden mosaic virus; BGYMV-DO = Bean golden yellow mosaic virus from the Dominican Republic; BGYMV-PR= BGYMV from Puerto Rico; BGYMV-GU = BGYMV from Guatemala; BGYMV-MX = BGYMV from Mexico; CaLCuV = Cabbage leaf curl virus; CdTV$\mathrm{TLCr}=$ Chino del tomate virus -Tomato leaf crumple strain; CLCrV = Cotton leaf crumple virus; CuLCrV-AZ = CuLCrV-Arizona isolate; PepGMV = Pepper golden mosaic virus; PHYVV = Pepper hausteco yellow vein virus; PYMV = Potato yellow mosaic virus; SiGMV = Sida golden mosaic virus; SLCV$[\mathrm{PH}]=$ Squash leaf curl virus-Philippines; SLCV = Squash leaf curl virus; SMLCV = Squash mild leaf curl virus; SYMoV = Squash yellow mottle virus; ToMHV-Qui = Tomato mosaic Havana virus from Quivican; ToMoTV = Tomato mottle taino virus; and ToMoV = Tomato mottle virus. CuLCrV-CA is shown in bold letters. Gray box = SLCV cluster of whitefly-transmitted begomoviruses. 
bombardment is time consuming and expensive, making it unsuitable for inoculation of large numbers of plants, such as is needed for germplasm screening. Thus, the agroinoculation method was developed. Agroinoculation allowed for the rapid and efficient inoculation of a large number of plants, making it more suitable for germplasm screening. This method also allows plants to be inoculated several times, over several different developmental stages.
Germplasm screening confirmed that many cantaloupe cultivars were susceptible to $\mathrm{CuLCrV}$ but also revealed a number of highly resistant cultivars. Thus, agroinoculation was used to identify CuLCrVresistant germplasm, which could be useful if $\mathrm{CuLCrV}$ became economically important in the Imperial Valley or elsewhere. Agroinoculation experiments also confirmed $\mathrm{CuLCrV}$ resistance in butternut squash, cucumber, and honeydew melon; however, in some plants, mild or symptomless infections were detected. Thus, these species should be considered highly resistant rather than immune. Symptomless infections by begomoviruses in hosts to which the viruses are not well adapted have been described previously, both in experimental systems and in the field $(18,34)$.

Brown et al. (5) confirmed results of Guzman et al. (15) that $\mathrm{CuLCrV}$ is a new
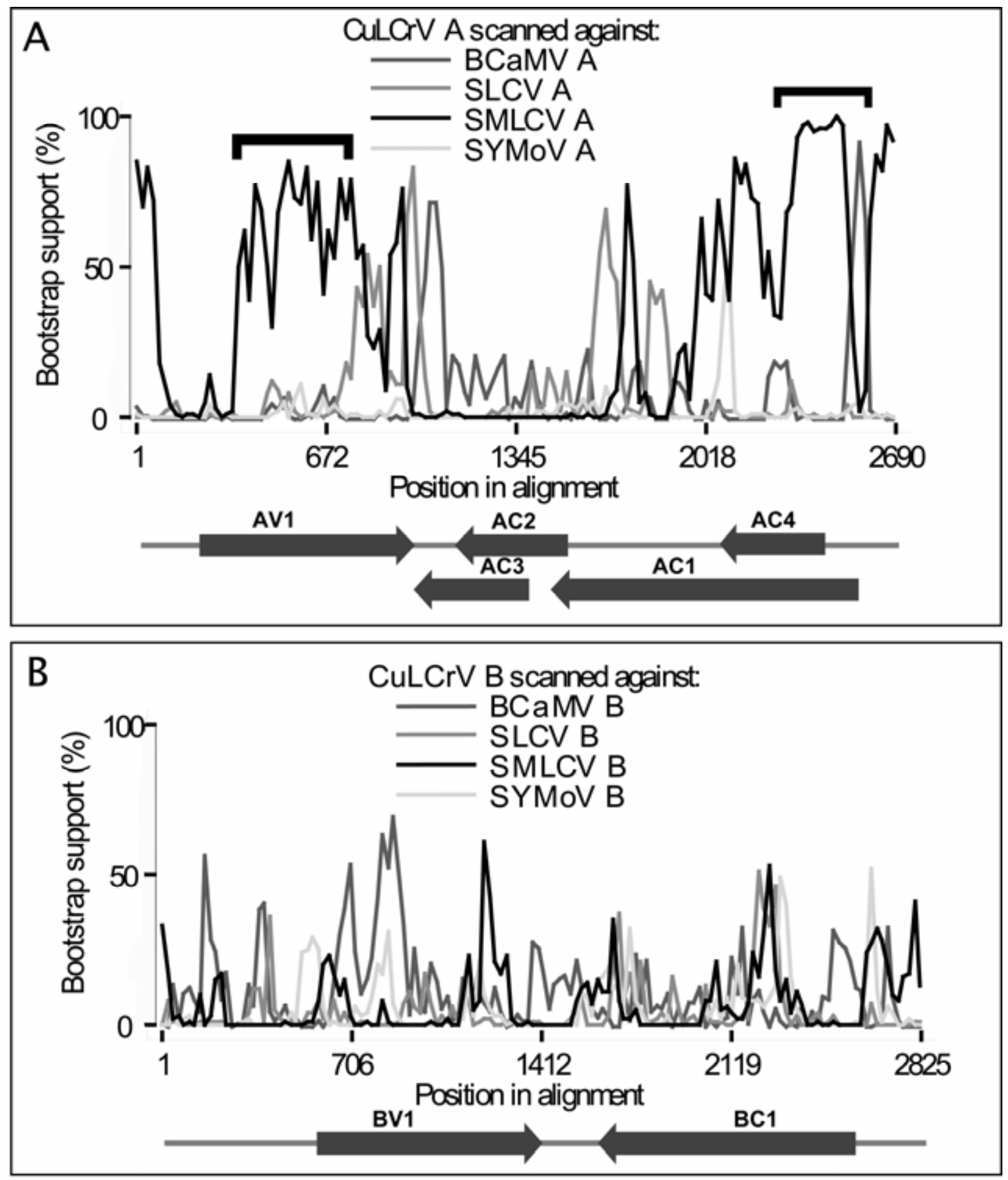

Fig. 6. Recombination analysis of the Cucurbit leaf crumple virus $(\mathrm{CuLCrV})$ genome. A, CuLCrV DNA-A and B, CuLCrV DNA-B were screened for potential recombination with Bean calico mosaic virus (BCaMV), Squash leaf curl virus (SLCV), Squash mild leaf curl virus (SMLCV), and Squash yellow mottle virus (SYMoV) using the RECSCAN algorithm. A higher level of bootstrap support suggests a higher probability of recombination with the compared virus. Brackets in A mark the regions where the highest probability of recombination between CuLCrV and SMLCV exists. 
bipartite Begomovirus sp. in the SLCV cluster. The high level of sequence identity between $\mathrm{CuLCrV}-\mathrm{CA}$ and CuLCrV-AZ $(>99 \%)$ and results of the phylogenetic analyses clearly show that these are isolates of a single begomovirus species. Despite this high level of genetic similarity, there may be some biological differences between CuLCrV-CA and CuLCrV-AZ. For example, CuLCrV-AZ was reported to induce symptomatic infections in both cucumber and honeydew melon, whereas CuLCrV-CA did not. These differences could reflect bona fide biological differences between the isolates, differences in inoculation methods, or differences in host genotypes used in these experiments.

$\mathrm{CuLCrV}$ is the first new Begomovirus sp. to be described in the desert southwest following the massive outbreaks of $B$. tabaci in the region beginning in the mid1990s. The origin of $\mathrm{CuLCrV}$ remains unknown, although it seems unlikely that it recently evolved from SMLCV (SLCV-R) or SLCV (SLCV-E), the most prevalent cucurbit-infecting Begomovirus sp. in the desert southwest, because of the high degree of sequence divergence and biological differences among these viruses. For example, $\mathrm{CuLCrV}$ infects a wider range of cucurbits than SMLCV; however, CuLCrV is poorly infectious in $N$. benthamiana, whereas SMLCV and SLCV are highly infectious and induce severe symptoms in this host. Finally, in preliminary whitefly transmission experiments, $\mathrm{CuLCrV}$ was considerably less transmissible by whiteflies compared with SLCV (12). However, because $\mathrm{CuLCrV}$ and SLCV or SMLCV cause similar symptoms in common hosts (e.g., squash [SMLCV or SLCV] and watermelon [SLCV]), the PCR test with the $\mathrm{CuLCrV}$ - and SLCV-specific primers can be used for the rapid and precise identification of these begomoviruses.

However, results of our RECSCAN sequence analysis suggested that the emergence of $\mathrm{CuLCrV}$ may well have involved recombination events with SMLCV in the $\mathrm{AC} 1$ and AV1 (CP) ORFs. This result is also consistent with Brown et al. (5), who reported higher sequence identities for the CuLCrV-AZ and SMLCV AC1 and AV1 ORFs compared with identities for the AC2 and AC3 ORFs. This may reveal a link between $\mathrm{CuLCrV}$, SMLCV, and a common ancestral Begomovirus sp. which may exist in weeds or some other reservoir host. The finding that CuLCrV-AZ can form viable pseudorecombinants with both SLCV and SMLCV (5) suggests a scenario for pseudorecombination and recombination among these viruses (17). The fact that the recombination occurred in the AC4 ORF is notable because the product of this gene acts as a gene-silencing suppressor protein (38). Thus, it is possible that the SMLCV AC4 provides an advantage to $\mathrm{CuLCrV}$ in terms of evading host defenses or altering host range. It will be of interest to determine whether a progenitor Begomovirus sp. exists in indigenous cucurbit species in the Imperial Valley, such as buffalo gourd (Cucurbita foetidissima), and the relationship of such a virus to CuLCrV.

In conclusion, we have characterized a California isolate of $\mathrm{CuLCrV}$ (CuLCrV$\mathrm{CA}$ ), and determined aspects of the biology, ecology, and epidemiology of the virus in the Imperial Valley. Although the virus has become established in the Imperial Valley and other parts of the desert southwest and northern Mexico, it has had minimal economic impact, in part due to a recovery phenotype in cantaloupe and watermelon. Were $\mathrm{CuLCrV}$ to become economically important, the identification of CuLCrV-resistant cucurbit cultivars, information about the biology of the virus, and tools for rapid detection of the virus should facilitate effective disease management.

\section{ACKNOWLEDGMENTS}

This research project was supported by grants from the California Melon Board and the University of California-Davis College of Agricultural and Environmental sciences. We thank J. Aguiar for providing samples from the Coachella Valley and arranging surveys of the area and N. Hernandez for excellent technical assistance.

\section{LITERATURE CITED}

1. Altschul, S. F., Madden, T. L., Schaffer, A. A., Zhang, J. H., Zhang, Z., Miller, W., and Lipman, D. J. 1997. Gapped BLAST and PSI-BLAST: a new generation of protein database search programs. Nucleic Acids Res. 25:3389-3402.

2. An, G. H. 1986. Development of plant promoter expression vectors and their use for analysis of differential activity of nopaline synthase promoter in transformed tobacco cells. Plant Physiol. 81:86-91.

3. Birdsall, S. L. 2006. 2005 agricultural crop \& livestock report Imperial county. Imperial County Agricultural Commissioner's Office, El Centro, CA.

4. Brown, J. K. 1994. Current status of Bemisia tabaci as a plant pest and a virus vector in agro-ecosystems worldwide. Plant Prot. Bull. 42:3-32.

5. Brown, J. K., Idris, A. M., Alteri, C., and Stenger, D. C. 2002. Emergence of a new cucurbit-infecting begomovirus species capable of forming viable reassortants with related viruses in the Squash leaf curl virus cluster. Phytopathology 92:734-742.

6. Carrillo-Tripp, J., Lozoya-Gloria, E., and Rivera-Bustamante, R. F. 2007. Symptom remission and specific resistance of pepper plants after infection by Pepper golden mosaic virus. Phytopathology 97:51-59.

7. Cohen, S., Duffus, J. E., Larsen, R. C., Liu, H. Y., and Flock, R. A. 1983. Purification, serology, and vector relationships of Squash leaf curl virus, a whitefly-transmitted geminivirus. Phytopathology 74:221-225.

8. Covey, S. N., Al-Kaff, N. S., Langara, A., and Turner, D. S. 1997. Plants combat infection by gene silencing. Nature 385:781-782.

9. Dellaporta, S. L., Wood, J., and Hicks, J. B. 1983. A plant DNA minipreparation: version II. Plant Mol. Biol. Rep. 1:19-21.

10. Flock, R. A., and Mayhew, D. E. 1981. Squash leaf curl, a new disease of cucurbits in California. Plant Dis. 65:75-77.

11. Garrido-Ramirez, E. R., Sudarshana, M. R., and Gilbertson, R. L. 2000. Bean golden yel- low mosaic virus from Chiapas, Mexico: characterization, pseudorecombination with other bean-infecting geminiviruses and germ plasm screening. Phytopathology 90:1224-1232.

12. Gilbertson, R. L. 2002. Incidence of virus infection in melons and host range and whitefly transmission of Cucurbit leaf crumple virus (CuLCrV) a new cucurbit-infecting geminivirus in California. Ann. Rep. Calif. Melon Res. Board

13. Gilbertson, R. L., Hidayat, S. H., Martinez, R. T., Leong, S. A., Faria, J. C., Morales, F., and Maxwell, D. P. 1991. Differentiation of beaninfecting geminiviruses by nucleic-acid hybridization probes and aspects of bean golden mosaic in Brazil. Plant Dis. 75:336-342.

14. Gilbertson, R. L., Rojas, M. R., Russell, D. R., and Maxwell, D. P. 1991. Use of the asymmetric polymerase chain reaction and DNA sequencing to determine genetic variability of Bean golden mosaic geminivirus in the Dominican Republic. J. Gen. Virol. 72:28432848.

15. Guzman, P., Sudarshana, M. R., Seo, Y. S., Rojas, M. R., Natwick, E., Turini, T., Mayberry, K., and Gilbertson, R. L. 2000. A new bipartite geminivirus (Begomovirus) causing leaf curl and crumpling in cucurbits in the Imperial Valley of California. Plant Dis. 84:488.

16. Hofer, P., Engel, M., Jeske, H., and Frischmuth, T. 1997. Nucleotide sequence of a new bipartite geminivirus isolated from the common weed Sida rhombifolia in Costa Rica. J. Gen. Virol. 78:1785-1790.

17. Hou, Y. M., and Gilbertson, R. L. 1996. Increased pathogenicity in a pseudorecombinant bipartite geminivirus correlates with intermolecular recombination. J. Virol. 70:5430-5436.

18. Hou, Y. M., Paplomatas, E. J., and Gilbertson, R. L. 1998. Host adaptation and replication properties of two bipartite geminiviruses and their pseudorecombinants. Mol. Plant-Microbe Interact. 11:208-217.

19. Isakeit, T., Robertson, N. L., Brown, J. K., and Gilbertson, R. L. 1994. First report of squash leaf curl virus on watermelon in Texas. Plant Dis. 78:1010.

20. Karkashian, J. P., Maxwell, D. P., and Ramirez, P. 2002. Squash yellow mottle geminivirus: a new cucurbit infecting geminivirus from Costa Rica. (Abstr.) Phytopathology 92:S125.

21. Kheyr-Pour, A., Bananej, K., Dafalla, G. A., Caciagli, P., Noris, E., Ahoonmanesh, A., Lecoq, H., and Gronenborn, B. 2000. Watermelon chlorotic stunt virus from the Sudan and Iran: sequence comparisons and identification of a whitefly-transmission determinant. Phytopathology 90:629-635

22. Lazarowitz, S. G. 1991. Molecular characterization of two bipartite geminiviruses causing squash leaf curl disease-role of viral replication and movement functions in determining host range. Virology 180:70-80.

23. Martin, D. P., Posada, D., Crandall, K. A., and Williamson, C. 2005. A modified bootscan algorithm for automated identification of recombinant sequences and recombination breakpoints. AIDS Res. Hum. Retrovir. 21:98-102.

24. Martin, D. P., Williamson, C., and Posada, D. 2005. RDP2: recombination detection an analysis from sequence alignments. Bioinformatics 21:260-262.

25. Morales, F., Niessen, A., Ramirez, B., and Castano, M. 1990. Isolation and partial characterization of a geminivirus causing bean dwarf mosaic. Phytopathology 80:96-101.

26. Morales, F. J., and Anderson, P. K. 2001. The emergence and dissemination of whiteflytransmitted geminiviruses in Latin Americabrief review. Arch. Virol. 146:415-441.

27. Page, R. D. M. 1996. TreeView: an application to display phylogenetic trees on personal computers. Comput. Appl. Biosci. 12:357-358.

28. Patel, V. P., Rojas, M. R., Paplomatas, E. J., 
and Gilbertson, R. L. 1993. Cloning biologically-active geminivirus DNA using PCR and overlapping primers. Nucleic Acids Res. 21:1325-1326.

29. Polston, J. E., and Anderson, P. K. 1997. The emergence of whitefly-transmitted geminiviruses in tomato in the western hemisphere. Plant Dis. 81:1358-1369.

30. Rojas, M. R., Gilbertson, R. L., Russell, D. R., and Maxwell, D. P. 1993. Use of degenerate primers in the polymerase chain reaction to detect whitefly-transmitted geminiviruses. Plant Dis. 77:340-347.

31. Rojas, M. R., Hagen, C., Lucas, W. J., and Gilbertson, R. L. 2005. Exploiting chinks in the plant's armor: evolution and emergence of geminiviruses. Annu. Rev. Phytopathol. 43:361-394.

32. Rojas, M. R., Jiang, H., Salati, R., XoconostleCazares, B., Sudarshana, M. R., Lucas, W. J., and Gilbertson, R. L. 2001. Functional analysis of proteins involved in movement of the monopartite begomovirus, Tomato yellow leaf curl virus. Virology 291:110-125.

33. Ruiz-Medrano, R., Xoconostle-Cazares, B., and Lucas, W. J. 1999. Phloem long-distance transport of CmNACP mRNA: implications for supracellular regulation in plants. Development 126:4405-4419.

34. Salati, R., Nahkla, M. K., Rojas, M. R., Guzman, P., Jaquez, J., Maxwell, D. P., and Gilbertson, R. L. 2002. Tomato yellow leaf curl virus in the Dominican Republic: Characterization of an infectious clone, virus monitoring in whiteflies, and identification of reservoir hosts. Phytopathology 92:487-496.

35. Seo, Y S., Gepts, P., and Gilbertson, R. L. 2004. Genetics of resistance to the geminivirus, Bean dwarf mosaic virus, and the role of the hypersensitive response in common bean. Theor. Appl. Genet. 108:786-793.

36. Sudarshana, M. R., Wang, H. L., Lucas, W. J., and Gilbertson, R. L. 1998. Dynamics of Bean dwarf mosaic geminivirus cell-to-cell and long-distance movement in Phaseolus vulgaris revealed, using the green fluorescent protein. Mol. Plant-Microbe Interact. 11:277-291.

37. Torres-Pacheco, I., Garzon-Tiznado, J. A., Brown, J. K., Becerra-Flora, A., and RiveraBustamante, R. F. 1996. Detection and distri- bution of geminiviruses in Mexico and the southern United States. Phytopathology 86:1186-1192.

38. Vanitharani, R., Chellappan, P., Pita, J. S., and Fauquet, C. M. 2004. Differential roles of AC2 and $\mathrm{AC} 4$ of cassava geminiviruses in mediating synergism and suppression of posttranscriptional gene silencing. J. Virol. 78:94879498

39. Wang, H., Sudarshana, M., Gilbertson, R. L. and Lucas, W. J. 1999. Analysis of cell-to-cell and long-distance movement of a Bean dwarf mosaic geminivirus-green fluorescent protein reporter in host and nonhost species: identification of sites of resistance. Mol. PlantMicrobe Interact. 12:345-355.

40. Wang, H. L., Gilbertson, R. L., and Lucas, W. J. 1996. Spatial and temporal distribution of Bean dwarf mosaic geminivirus in Phaseolus vulgaris and Nicotiana benthamiana. Phytopathology 86:1204-1214.

41. Wyatt, S. D., and Brown, J. K. 1996. Detection of subgroup III geminivirus isolates in leaf extracts by degenerate primers and polymerase chain reaction. Phytopathology 86:1288-1293. 